\title{
Structural model of attachment styles, early maladaptive schemas and health dimensions by mediating coping styles
}

\author{
Elham Faramarzinia ${ }^{1}$, Sayvid Abdul Majid Bahrainian ${ }^{2}$, Mehdi Manouchehri ${ }^{3}$ \\ ${ }^{1}$ PhD Candidate of Psychology, Department of Psychology, Islamic Azad University, Tehran Markazi Branch, Tehran, \\ Iran \\ ${ }^{2}$ Professor, Department of Psychology, Tehran University of Medical Sciences, Islamic Azad University, Tehran, Iran \\ ${ }^{3}$ Assistant Professor, Department of Psychology, Tehran University of Medical Sciences, Islamic Azad University, \\ Tehran, Iran
}

\begin{abstract}
Background: Knowing the variables affecting health is clinically important. The purpose of this study was to determine the mediating role of coping styles in relation between attachment styles and early maladaptive schemas and health dimensions.

Materials and methods: In a descriptive study, 500 students from Azad University of Medical Sciences of Tehran between 2017 and 2018 were selected by available sampling method. Participants (250 female and 250 male) were asked to complete questionnaires of adult attachment scales, early maladaptive schemas, coping styles, and general health. Data analysis was performed using structural equation modeling.

Results: The results showed that the tested model had suitable fit. There was a significant negative relationship between subscales of attachment styles other than secure attachment with dimensions of health. In the early maladaptive schemas scale, other than the sub-scale of the other direction, the other subscales had a significant negative relationship with the dimensions of health. In the scale of coping styles, there was a significant positive correlation between problem-oriented strategy subscales, and emotional-oriented strategies had a negative significant relation with health dimensions, The results also showed that coping styles had mediating role in the relationship between attachment styles and early maladaptive schemas with health dimensions.

Conclusion: These findings, while pointing to the complexity of attachment nature, early maladaptive schemas and coping styles, emphasize the identification and conceptualization of various variables affecting health.
\end{abstract}

Keywords: Attachment styles, Early maladaptive schemes, Coping styles, Health dimensions.

Cited as: Faramarzinia E, Bahrainian SAM, Manouchehri M. Structural model of attachment styles, early maladaptive schemas and health dimensions by mediating coping styles. Medical Science Journal of Islamic Azad University, Tehran Medical Branch 2019; 29(4): 337-348.

Correspondence to: Sayyid Abdul Majid Bahrain

Tel: +989123447617

E-mail: majid.bahrainian@gmail.com

ORCID ID: 0000-0003-2819-2182

Received: 20 May 2018; Accepted: 3 Sep 2018 
مجله علوم يزشكى دانشكاه آزاد اسلامى

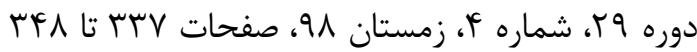

Original

Article

\section{مدل ساختارى سبكهاى دلبستگى، طر حوارههاى ناسازگار اوليه و ابعاد سلامت با ميانجى}

الهام فرامرزى نيا'، سيد عبدالمجيد بحرينيان؛'، مهدى منوجهرى

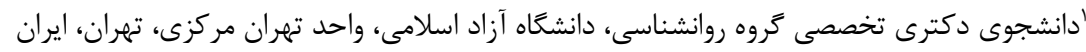

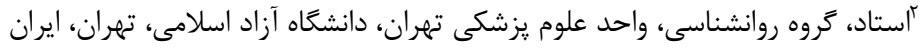

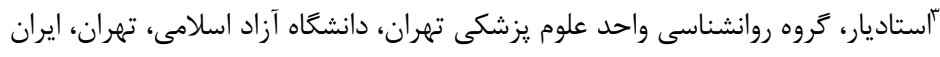

جككيه

سابقه و هدف: آعاهى /ز متغيرهاى تاثيركذار بر سلامت /ز نظر بالينى اهميت فراوانى دارد. يزوهش حاضر با هدف تعيين نقش

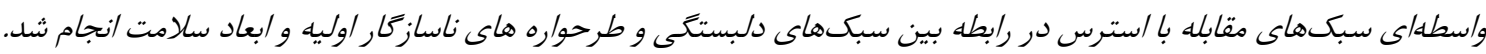

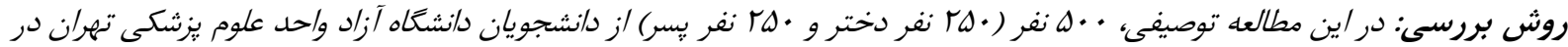

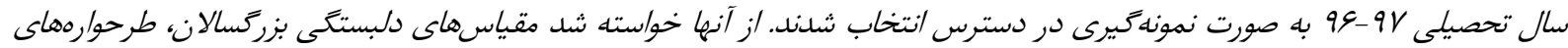

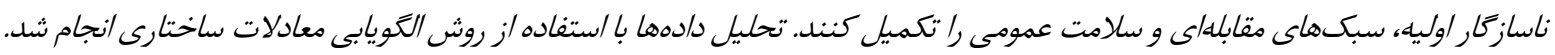

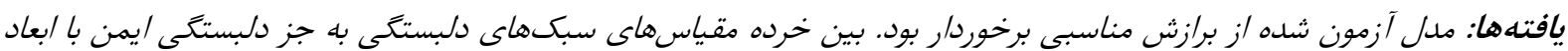

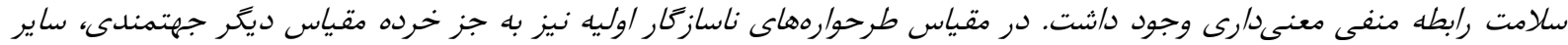

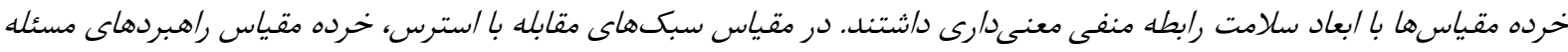

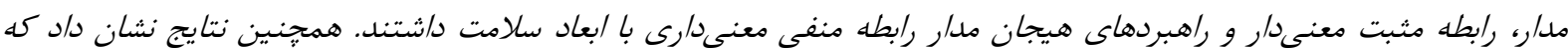

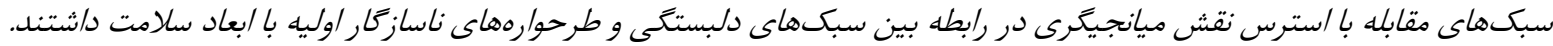

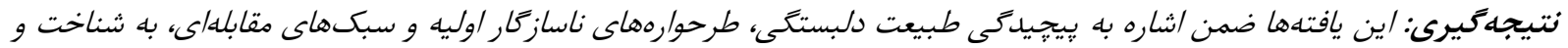

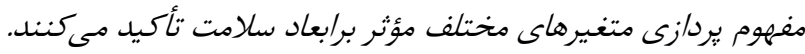

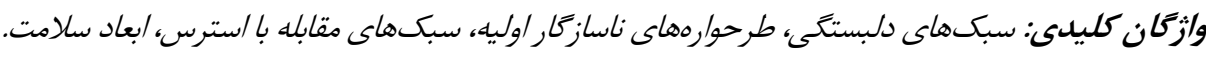

كه مطالعات انجام شده در سالهاى اخير، رابطه تنكَاتنكى بين مقدمه

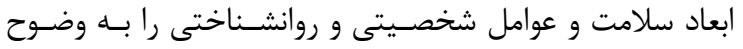

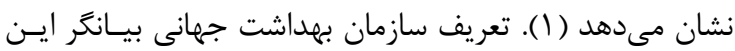

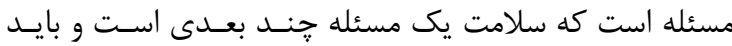

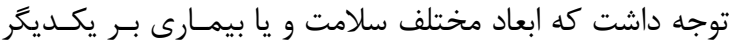

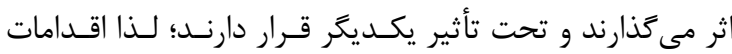

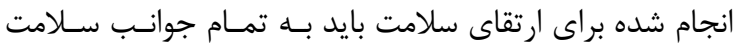

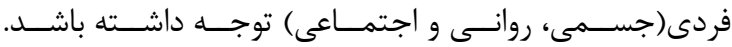

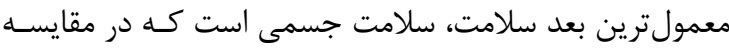

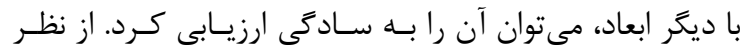

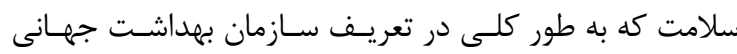
(WHO)

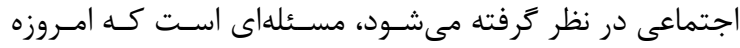

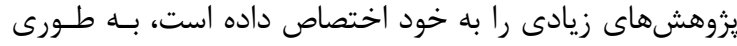

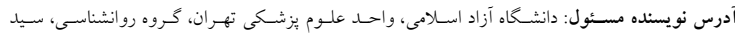

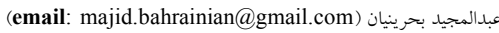
ORCID ID: 0000-0003-2819-2182

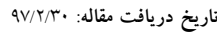
تاريخ هذيرش مقاله: QV/ 


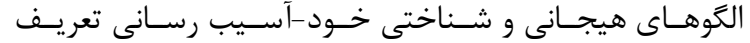

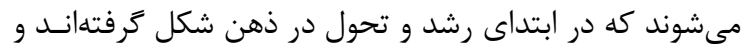

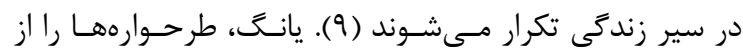

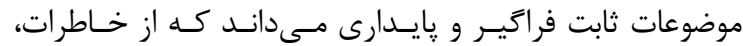

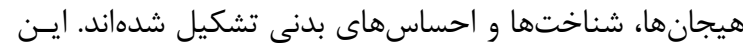

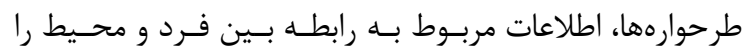

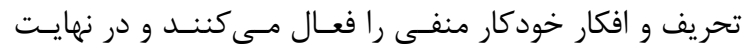

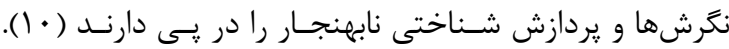

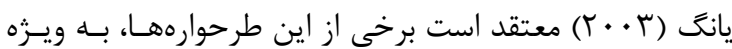

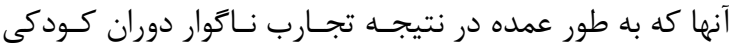
شكل مى گيرند، ممكن است هسته اصلى اختلالات شخصـيت،

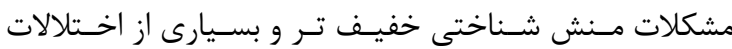

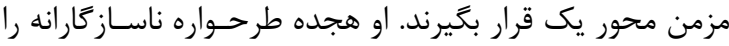

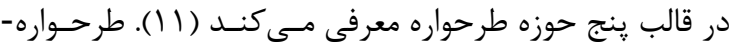

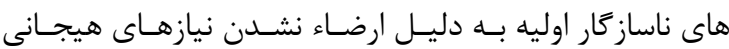

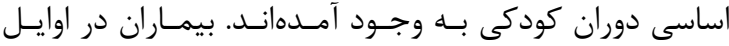

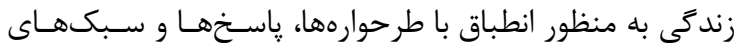

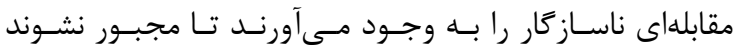
هيجانهاى شديد و استيصال كننده را تجربه كنــد، ايـن كـار

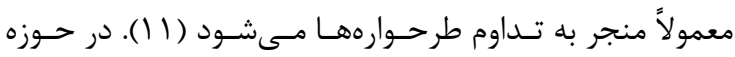

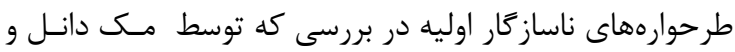

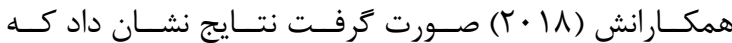

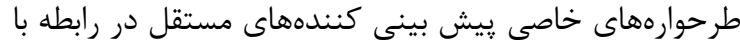

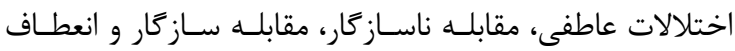

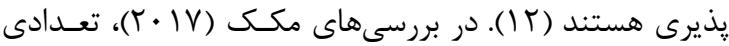

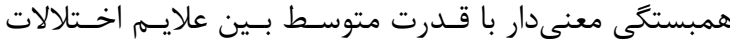

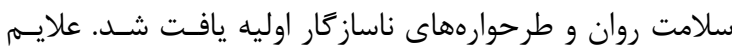

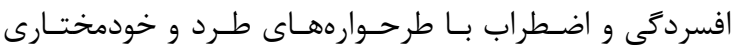
مختل مرتبط بودند. همبستخى هاى ديكر سلامت با طرحوارهها

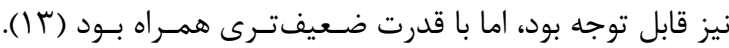

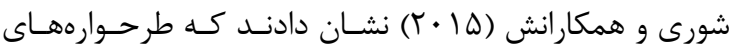

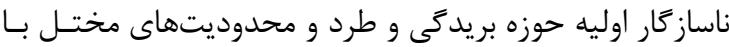

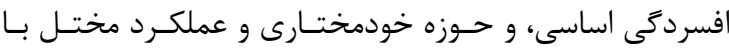

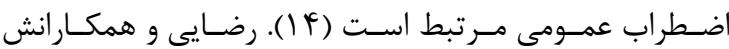

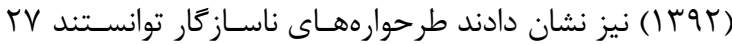

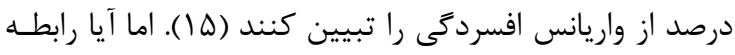
بين سبكهاى دلبستكى و طرحوارههاى ناساز كار اوليه با ابعـاد

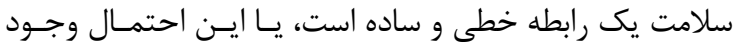
دارد كه متغيرهاى ديخرى در اين رابطه نقش واسطهاى داشته

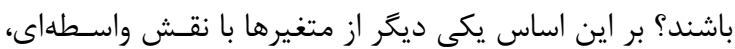

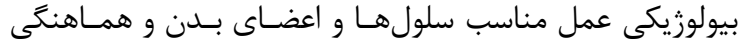

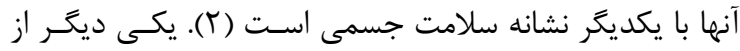

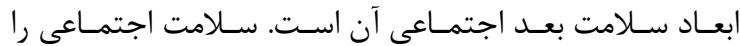

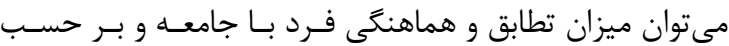
حمايت اجتماعى و نحوه ايفاى نقش او در جامعه تعريـف كرد

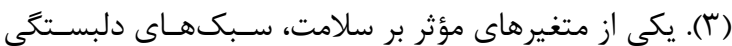

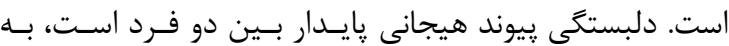

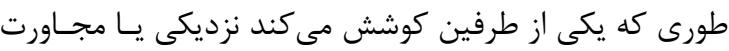

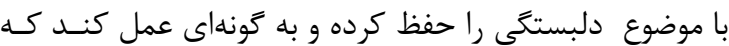

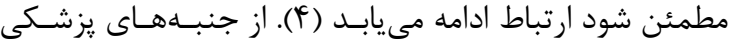

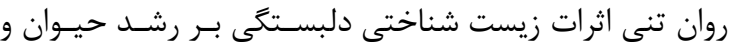

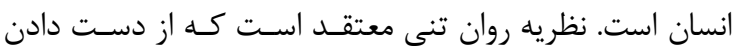

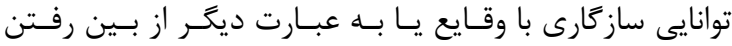

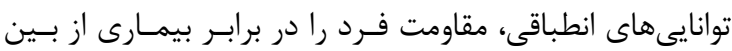

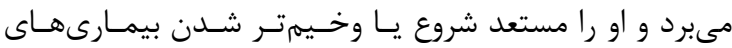

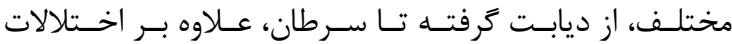
روانشناختى مى كند كه اين توانايىهاى انطباقى مى تواند تحت

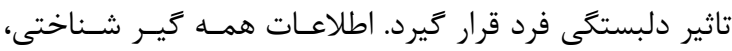

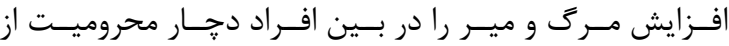

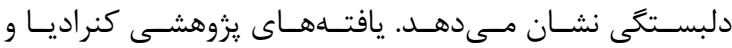

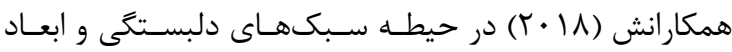

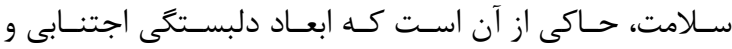

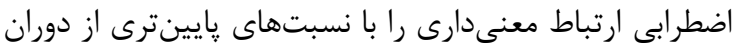

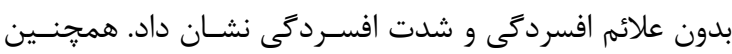
سبك دلبستخى ايمن در مقايسه با سبك دلبستكى دلمشـغول

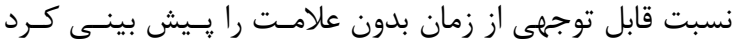

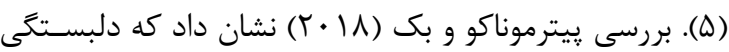
نايمن (اضطرابى/ يا اجتنابى) با پاسخهاى فيزيولوزيكى كنترل نشده به استرس، رفتارهاى بهداشتى خطرناك، حساسـيت بـاسه بيمارىهاى جسمى و نتايج بدتر بيمارىهـا مـرتبط اسـت (9) (9).

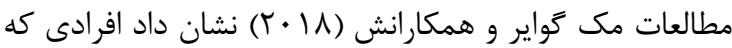
داراى دلبستكى نايمن هستند بيشتر احتمال دارد كـه علائسم

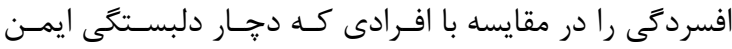

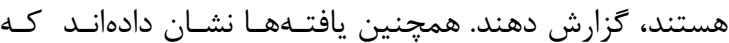

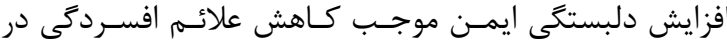

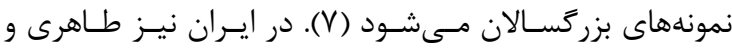

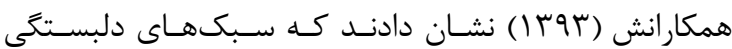

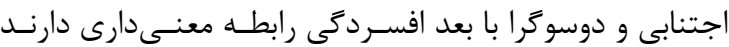

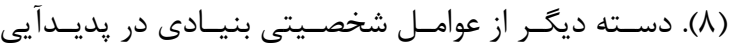

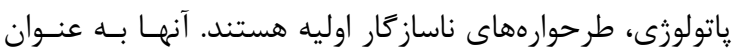




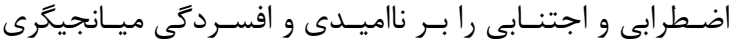

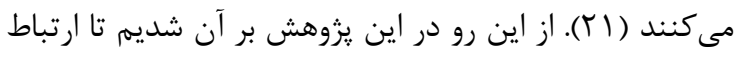
بين سبكهاى دلبستخى، طرحوارههاى ناسازگًار اوليـه و ابعـاد

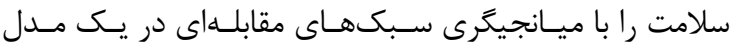
ساختارى مورد بررسى قرار دهيم.

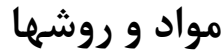

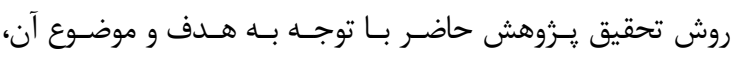

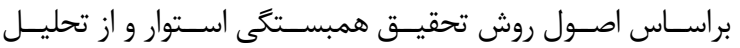

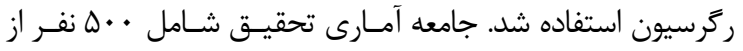

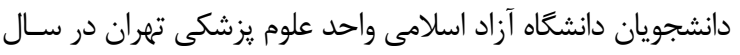

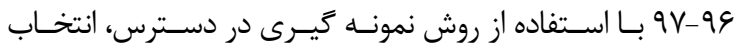

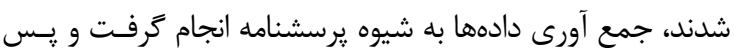

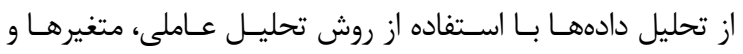

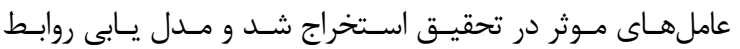

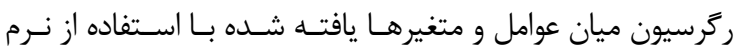

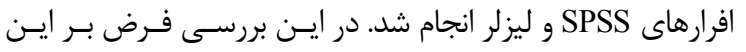

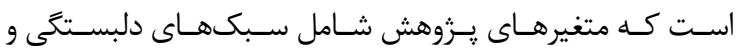
طرحوارههاى ناساز كار اوليه به طور مستقيم و نيز از طريق سـبكـ

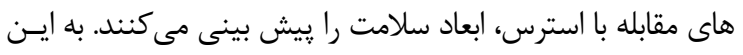

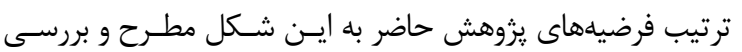

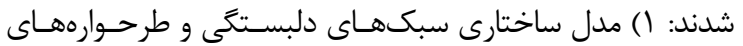

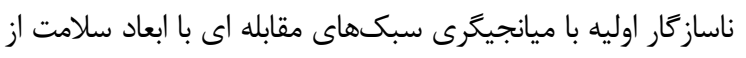

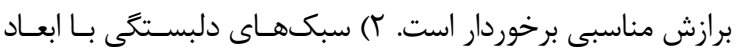

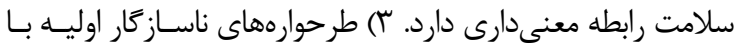
ابعاد سلامت رابطه معنى دارى دارد. \&) سبكهاى مقابلهادى بار با ابعـاد

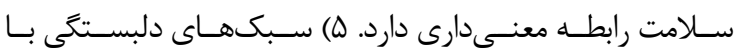

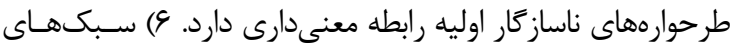

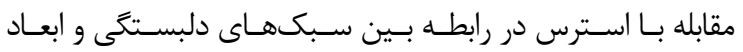

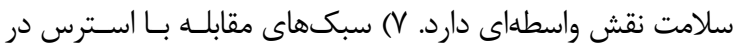

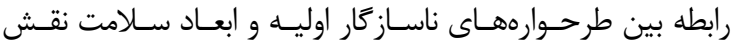

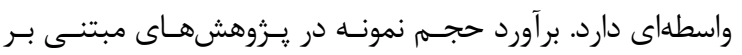

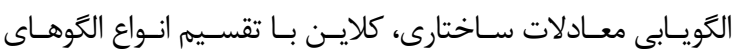

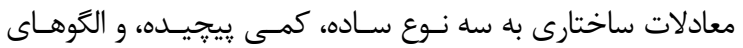

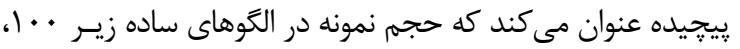

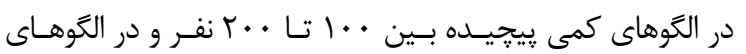

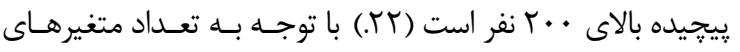

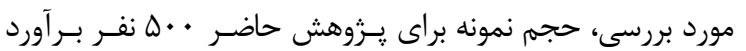

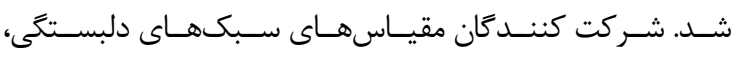

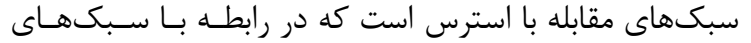

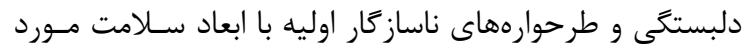

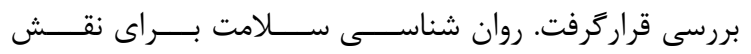

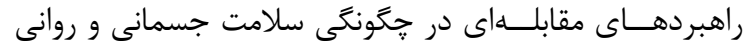

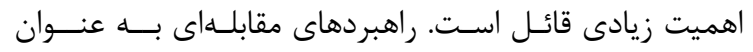

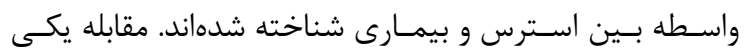

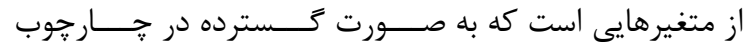

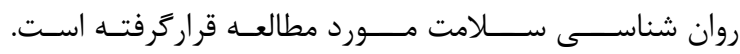
شناسايى شكلهاى موثر مقابله بـه عنوان متغيــر واسططهاى در

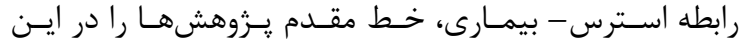

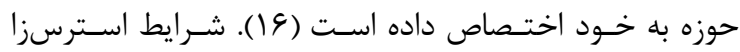

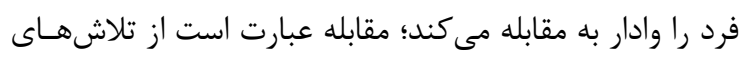

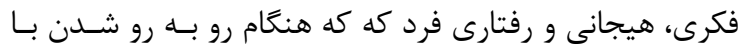

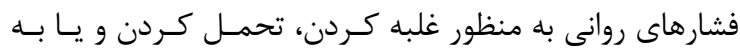

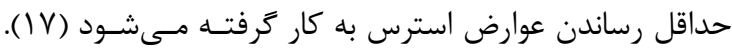

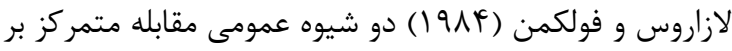

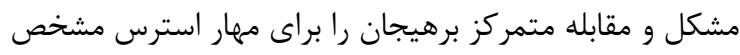

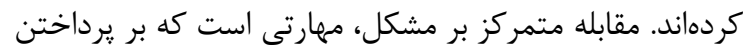

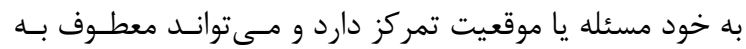

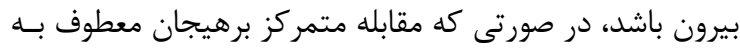

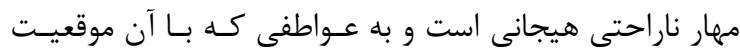

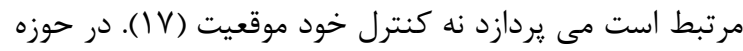

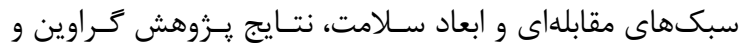

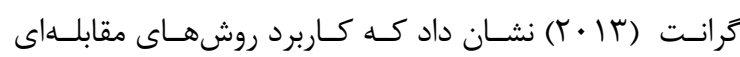

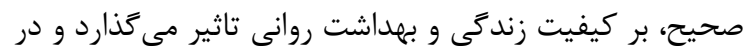

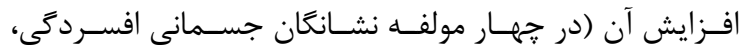
اضطراب و كاركرد اجتماعى) نقش مهمى را را ايفا مى كنـــ (1) (1).

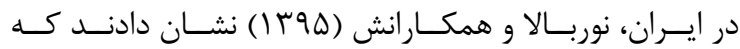

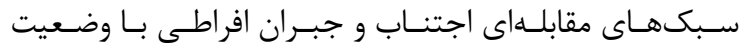

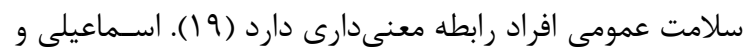

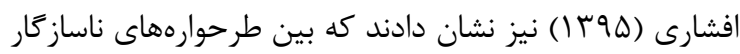
اوليه با سبكهاى مقابلهاى در مولفههاى اجتنابى، مهاركرى در دران

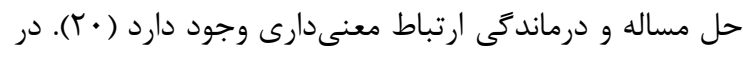

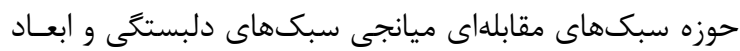

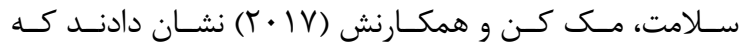
زندانيانى كه سابقه رفتار خودكشى دارند، به طور قابل تـوجهى

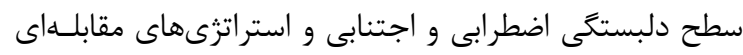

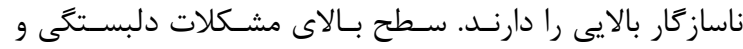

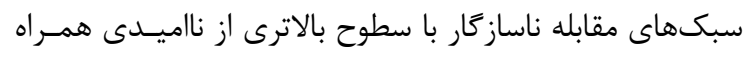

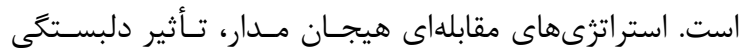


ضرايب آلفاى كرونباخ يرسشهاى زير مقياسهاى ايمن، اجتنسبى

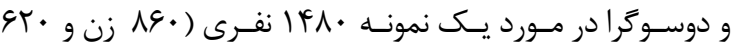

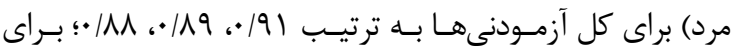

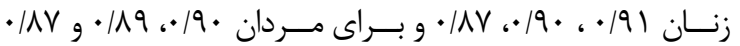

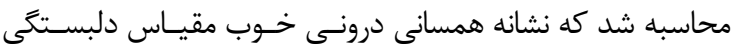

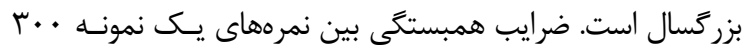

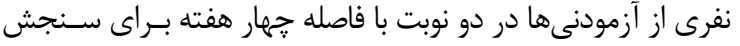

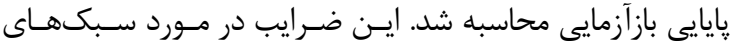

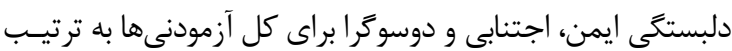

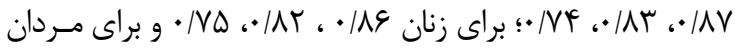

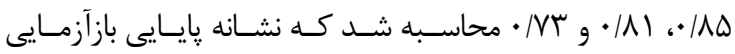

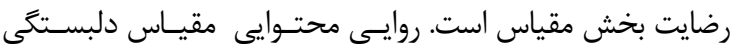

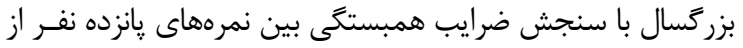

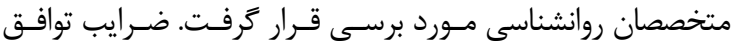

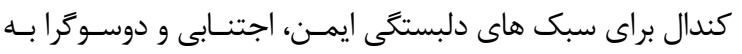

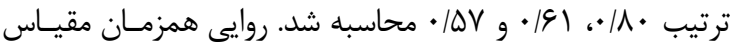

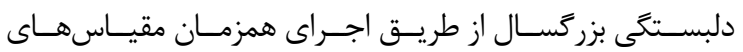

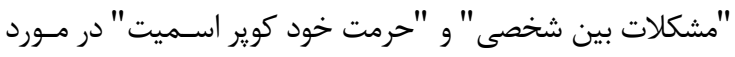

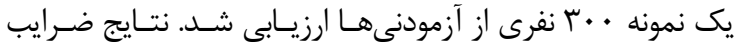

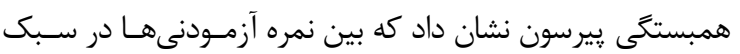

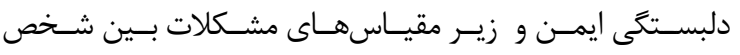

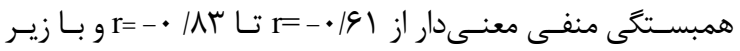

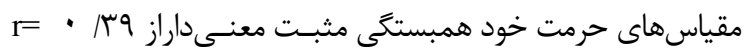

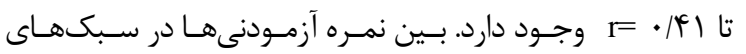

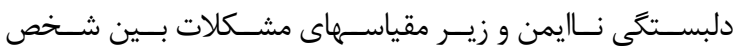

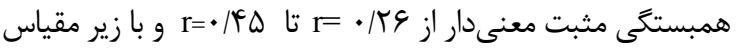

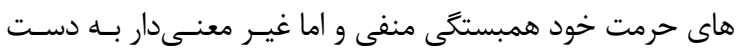

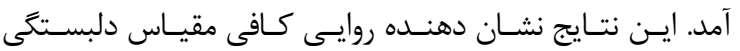

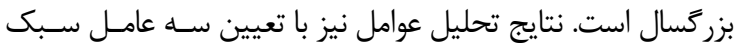

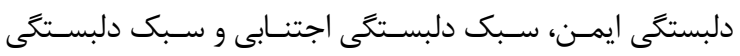

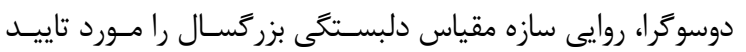

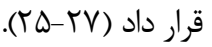

\section{يرسشنامه طرحوارههاى ناســازگًار اوليـهـ يانــَ: ايـن}

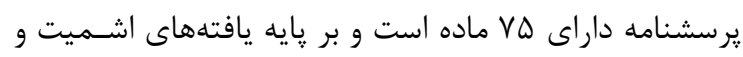

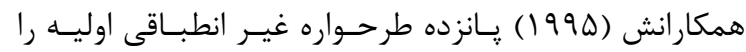
ارزيابى مى كند. اين يرسشنامه توسط يانگ و بـراون (1994)

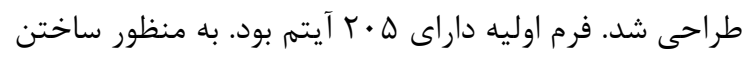

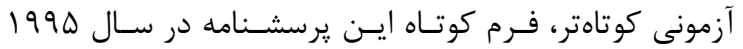

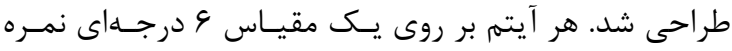

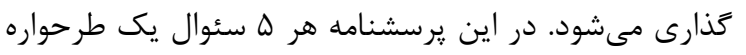

طرحوارههاى ناسازگًار اوليه، سبكهاى مقابلهاى و سلامت عمـومى

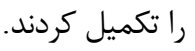

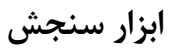
يرسشنامه سلامت عمومى: يك يرسشنامه غربالكرى مبتنى بـر

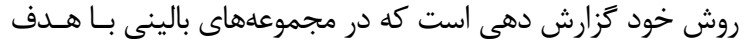

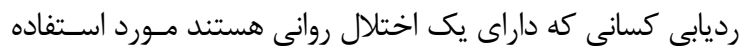

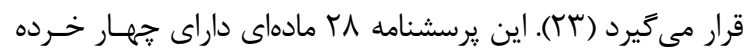

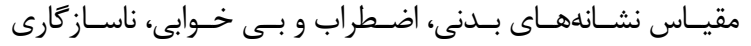

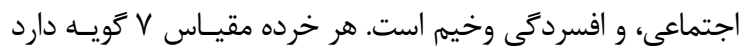

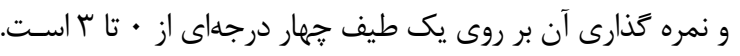

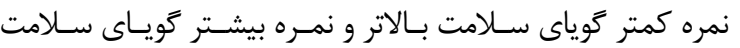

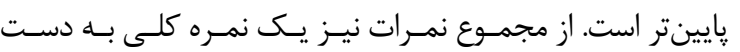

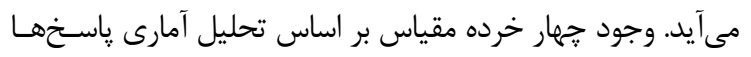

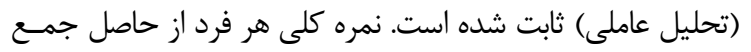

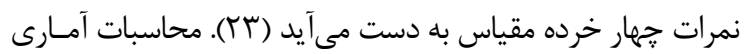

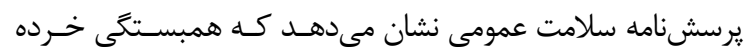

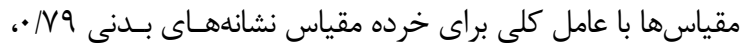

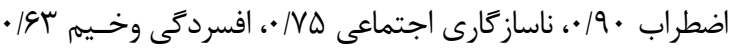

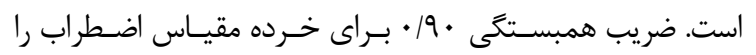

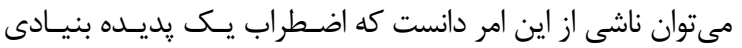

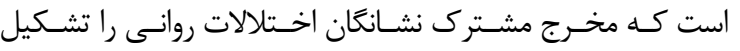

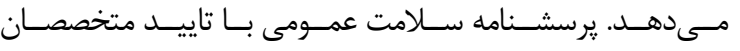

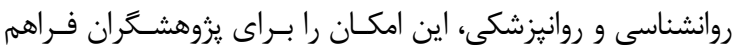

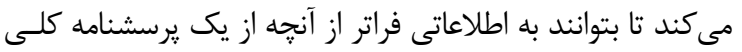

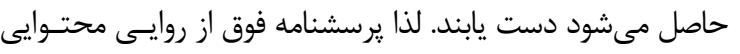

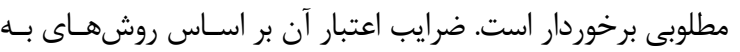

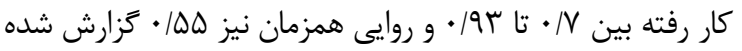

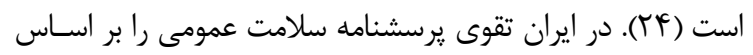

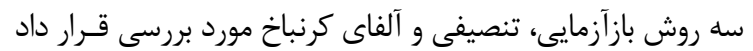

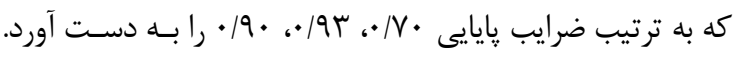

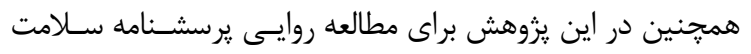

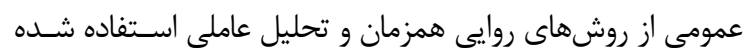

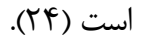

يرسشنامه سبكهاى دلبستخى بزرَّال: مقياس دلبستگى

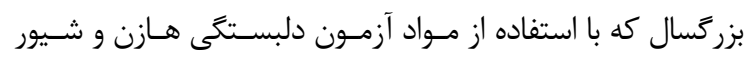

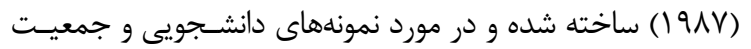

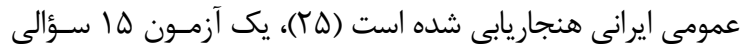

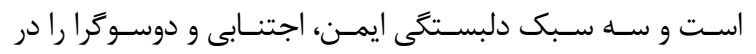

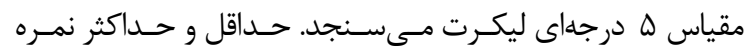

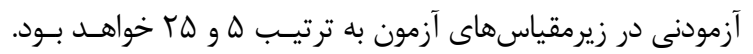




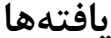

در اين يزوهش به منظور تحليل دادهها، از تحليلهاى

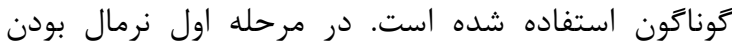
دادهها با استفاده از آزمون كولموكروف- اسميرنوف و ونداده

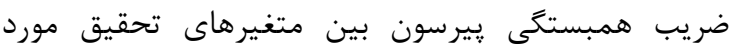
بررسى قرار گرفت كه در جدولهاى ا و ب ارائه شده است.

\begin{tabular}{|c|c|}
\hline سطح معنى دارى & ابعاد/ مولفه \\
\hline שTr/ & ابعاد سلامت \\
\hline .1148 & طر حواره هاى ناسازگًار اوليه \\
\hline.$/ 1 r q$ & سبكهاى مقابله اى \\
\hline$\cdot|| \Delta \mid$ & سبكهاى دلبستىى \\
\hline
\end{tabular}

\begin{tabular}{|c|c|c|c|c|}
\hline F & $r$ & r & 1 & متغيرها \\
\hline & & & $1 / \cdot \cdot$ & ابعاد سلامت \\
\hline & & $1 /$. & $-\cdot|\Delta \Lambda|^{* * B}$ & طرحوار ههاى ناساز كار اوليه \\
\hline & $1 /$. & $\cdot / イ \vee=$ & $\cdot \mid \pi 9 r^{* *}$ & سبكهاى مقابلهاى \\
\hline $1 /$. & . $/ \& \vee q^{\text {wath }}$ & $\cdot / \Delta \vee \Delta^{* * *}$ &.$- / r \Delta V^{*}$ & سبكهاى دلبستخى \\
\hline
\end{tabular}

با توجه به اينكه سطح معنىدارى براى متغيرهاى تحقيق بزركتر

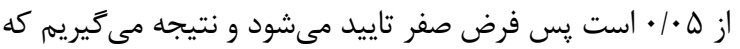

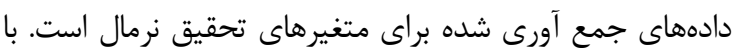
توجه به نتايج بدست آمده از ضريب همبستكى بيرسون بين متغيرهاى تحقيق مىتوان كفت بين همه متغيرها در سطح

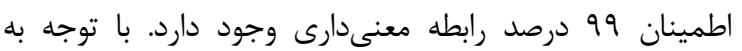

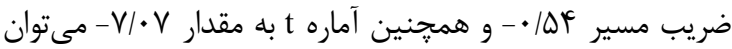
كفت: سبكهاى دلبستگى در سطح اطمينان 99 درصد بر ابعاد سلامت تاثير منفى و معنىدارى دارد؛ بنابراين فرضيه سبكهاى دلبستخى با ابعاد سلامت رابطه معنى دارى دارد، تاييد مىشودائ

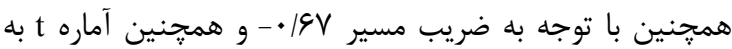

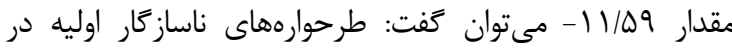
سطح اطمينان 99 درصد بر ابعاد سلامت تاثير منفى و معنى داردارى دارد؛ بنابراين فرضيه طرحوارههاى ناساز

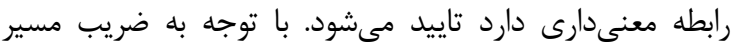

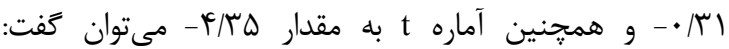
سبكهاى مقابلهاى در سطح اطمينان 99 درصد بر ابعاد سلامت تاثير منفى و معنى دارى دارد؛ بنابراين فرضيه سبكهاى مقابلهایى با ابعاد سلامت رابطه معنىدارى دارد نيز تاييد مىشودد. مقدار

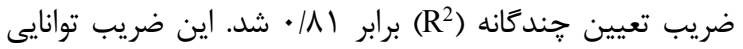

را مسىسـنجد. در مطالعـه ولبــرن، كوريسـتين، داك، يونست

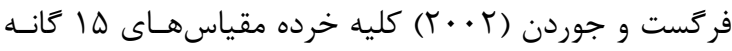
فرم كوتاه يرسشنامه طرحوارهها از همسانى درونسى كـافى تـا لـا

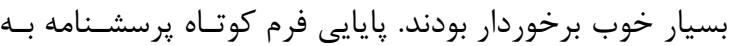

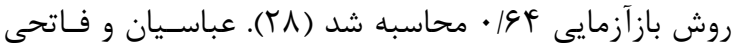

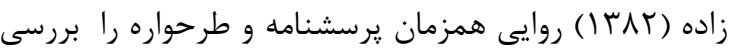

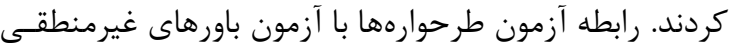

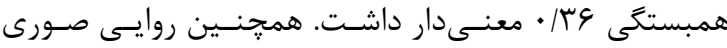

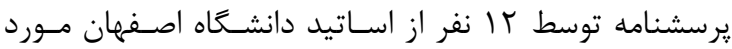
تاييد قرار كرفت. هر آيتم به وسيله مقيـاس درجـهـ بنـــى

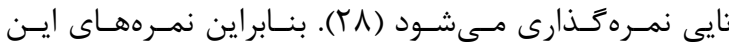

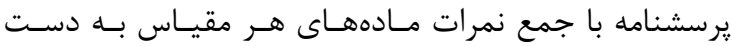

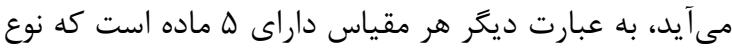

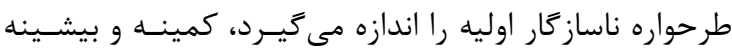

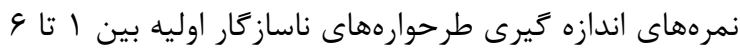

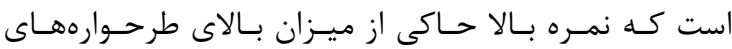

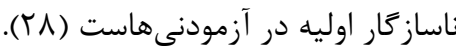
يرسشنامه سبكهــاى مقابلـهاى لازاروس و فــولكمن: براى سنجش راهبردهاى مقابلهاى بر مبناى نظريه لازاروس و و

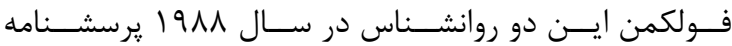

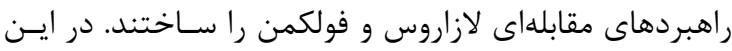

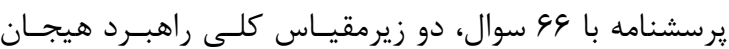

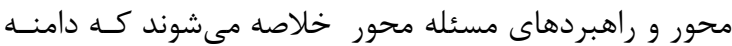

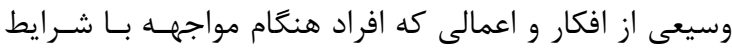

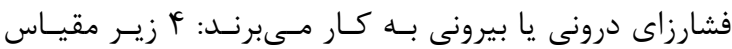
جستجوى حمايت اجتماعى، مسوليت يذيرى، مسئله گشـايى دئ

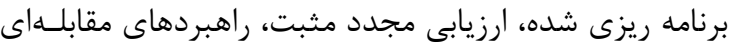

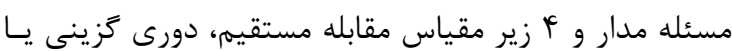

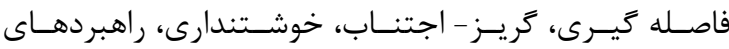

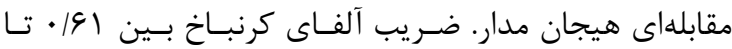

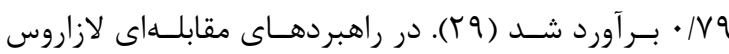

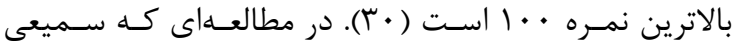

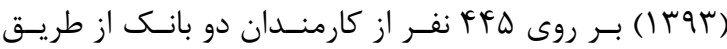

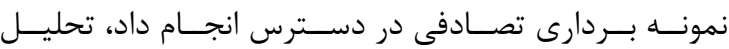

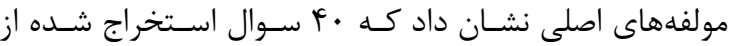

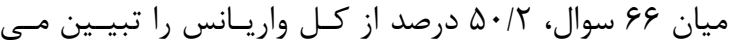

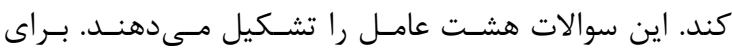

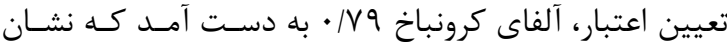
مى دهد اين يرسشنامه از اعتبار بالايى برخوردار است (آ). 
هاى مقابلهاى بر ابعاد سلامت اثر غير مستقيم دارد. در حوزه سبكهاى دلبستخى با توجه به ضريب مسير 1 ••|•- و همجنين

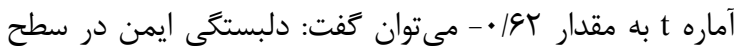

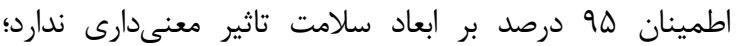
بنابراين فرضيه فرعى دوازدهم يثرهش معنى دار نيست و تاييد نمىشود. با توجه به ضريب مسير

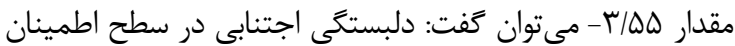
99 درصد بر ابعاد سلامت تاثير منفى و معنى دارى دارد؛ بنابراين

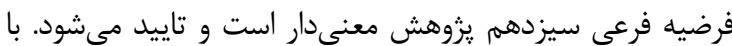

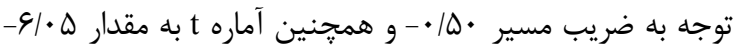
مى توان گفت: دلبستخى دوسوگرا در سطح اطمينان 99 درصد بر ابعاد سلامت تاثير منفى و معنى دارى دارد؛ بنابراين فرضيه فرعى درئي جهاردهم يزوهش معنى دار است و تاييد مىشود. مقدار ضريب تعيين ₹ند
بيش بينى متغير وابسته توسط متغير مستقل را بررسى مى كند. بر اين اساس متغيرهاى سبكهاى دلبستگى، طرحوارههاى

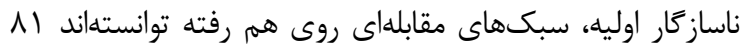
درصد از تغييرات متغير ابعاد سلامت را ييش بينى كنند كه اين نتايج در جدول r نشان داده شده است. در فرضيه سبكهاى مقابله با استرس در رابطه بين سبكهاى دلبستگى و ابعاد سلامت نقش واسطهاى دارد. با توجه به اينكه مقدار بدست آمده

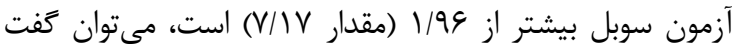
سبكهاى دلبستخى با ميانجيخرى سبكهاى مقابلهاى بر ابعاد سلامت اثر غير مستقيم دارد. همجنين در فرضيه سبكهاى مقابله با استرس در رابطه بين طرحوارههاى ناساز ₹ار اوليه و ابعاد سلامت نقش واسطهاى دارد، نيز با توجه به اينكه مقدار

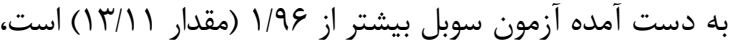
مى توان گفت طرحوارههاى ناسازگًار اوليه با ميانجيگرى سبك-

جدول ץ ـ ضرايب مسير،آماره t و ضريب تعيين (متغير وابسته:ابعاد سلامت)

\begin{tabular}{|c|c|c|c|}
\hline ضريب تعيين كل (R²) & t t t t & ضريب مسير [] & متغير پيش بين \\
\hline \multirow{3}{*}{$\cdot|\Lambda|$} & $-V / \cdot V^{*}$ & $-\cdot \mid \Delta F$ & سبكهاى دلبستتى \\
\hline & $-11 / \Delta 9 \%$ & $-\cdot \mid 9 V$ & طرحواره هاى ناسازگًار اوليه \\
\hline & $-\varphi / \Gamma \Delta^{*}$ & $-\cdot|\mu|$ & سبكهاى مقابله اى \\
\hline
\end{tabular}

جدول F. ضر ايب مسير، آماره tو ضريب تعيين (متغير وابسته: ابعاد سلامت)

\begin{tabular}{|c|c|c|c|}
\hline ضريب تعيين كل (R²) & آماره t & ضريب مسير(ß) & متغير يِيش بين \\
\hline \multirow{3}{*}{ - } & $-.19 T$ & $-\cdot / \cdot \wedge$ & دلبستتى ايمن \\
\hline & $-\Gamma / \Delta \omega^{\text {券䖭 }}$ & $-\cdot / T V$ & دلبستكگى اجتنابى \\
\hline & $-91 \cdot \Delta^{* * *}$ & $-\cdot / 0 \cdot$ & دلبستخى دوسوكَرا \\
\hline
\end{tabular}

جدول ه. ضرايب مسير، آماره t و ضريب تعيين (متغير وابسته: ابعاد سلامت)

\begin{tabular}{|c|c|c|c|}
\hline ضريب تعيين كل (R2) & 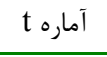 & ضريب مسير (م) & متغير ييش بين \\
\hline \multirow{5}{*}{.199} & $-9 / 94 \gamma^{2}$ & $-.19 \Lambda$ & بريدگى و طرد \\
\hline & $-V / 9 \Delta^{* * * *}$ & $-\cdot 1 \Delta \varphi$ & خود خردانى و عملكرد مختل \\
\hline & $-\cdot|\wedge|$ & $-\cdot 1 \cdot 9$ & ديخرجهتمندى \\
\hline & $-9 / \Gamma \Lambda^{\text {क** }}$ &.$- / 49$ & كوش بزنكى بيش از حد و بازدارى \\
\hline & $-\Delta / q^{4}$ & ( & محدوديتهاى مختل \\
\hline
\end{tabular}

جدول 9. ضرايب مسير، آماره tو ضريب تعيين (متغير وابسته :ابعاد سلامت)

\begin{tabular}{|c|c|c|c|}
\hline ضريب تعيين كل (R2) & t آماره t & ضريب مسير (م) & متغير پيش بين \\
\hline & Y/\&T*** & $\cdot / \pi \wedge$ & سبكهاى مسئله مدار \\
\hline . & $-r / r \digamma * * *$ & $-\cdot / r \Delta$ & سبكهاى هيجان مدار \\
\hline
\end{tabular}


با اين فرضيه كه ديخر جهتمندى با ابعاد سلامت رابطه منفى معنى دارى دارد، نشان داد كه با توجه به ضريب مسير

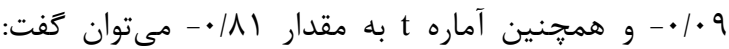

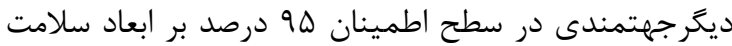
تاثير معنى دارى ندارد؛ بنابراين اين فرضيه يروهش معنى دار

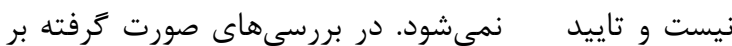
روى اين فرضيه كه گوش بزنگى بيش از حد و بازدارى با

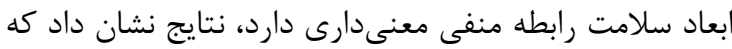

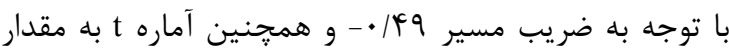

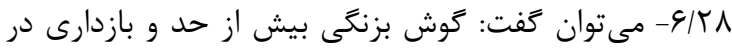
سطح اطمينان 99 درصد بر ابعاد سلامت تاثير منفى و معنى دارى دارد؛ بنابراين اين فرضيه يثوهش معنى دار است و تاييد مىشود. در ارتباط با اينكه محدوديتهاى مختل با بـ بـ ابعاد سلامت رابطه منفى معنى دارى دارد، نتايج نشان داد كه

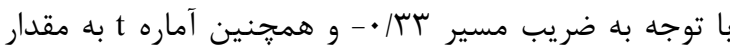

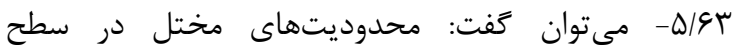
اطمينان 99 درصد بر ابعاد سلامت تاثير منفى و معنى دارى دارد؛ بنابراين اين فرضيه يزوهش نيز معنىى دار است و تاييد مىشود. مقدار ضريب تعيين هند
بينى متغير وابسته توسط متغير مستقل را بررسى مى كند. بر اين

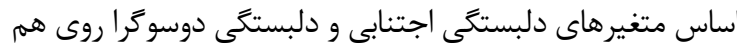

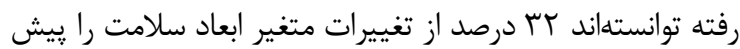
بينى كنند. متغير دلبستگى ايمن سهم معنى دارى در ييش بينى

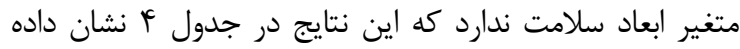

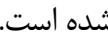
در حوزه طرحوارههاى ناسازگار اوليه در اتباط با فرضيه بريدگى و طرد با ابعاد سلامت رابطه منفى معنى دارى دارد.

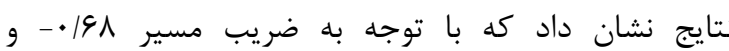

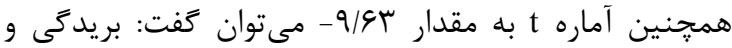
طرد در سطح اطمينان 99 درصد بر ابعاد سلامت تاثير منفى و معنى دارى دارد؛ بنابراين اين فرضيه يزوهش معنى دان دار است و تاييد مىشود. نتايج تحليلها در ارتباط با اين فرضيه كه

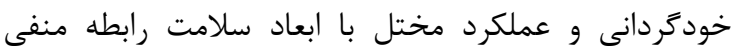
معنى دارى دارد، نشان داد كه با توجه به ضريب مسير وله • • -

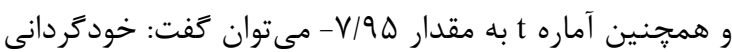
و عملكرد مختل در سطح اطمينان 99 درصد بر ابعاد سلامت تاثير منفى و معنى دارى دارد؛ بنابراين اين فرضيه يروهش نيز معنى دار است و تاييد مىشود. نتايج تحليلها در ارتباط

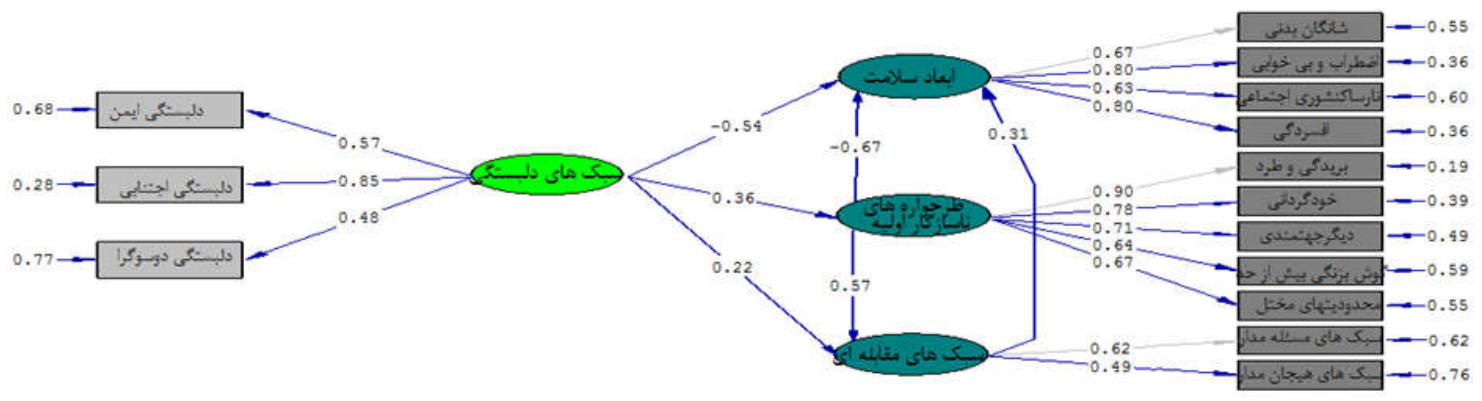

Chi-Square-154.79, df 7 , P-value=0.08340, RMSEA-0.048

شكل ا. مدلسازى معادلات ساختارى مدل مفهومى تحقيق (تخمين استاندارد)

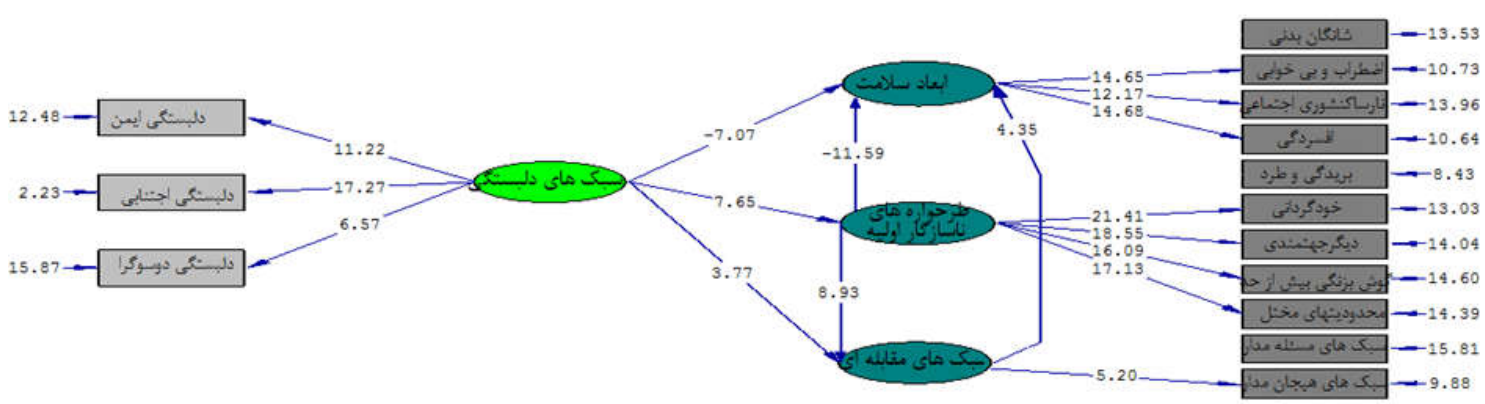

Chi-Square=154.79, df $=7$, P-value=0.08340, RMSEA-0.048

شكل r. مدلسازى معادلات ساختارى مدل مفهومى تحقيق (معنىدارى ضرايب) 


\begin{tabular}{|c|c|c|}
\hline مقدار به دست آمده & حد مجاز & نام شاخص \\
\hline$T / 1 \Lambda$ & rو كمتر & $\mathrm{X} 2 / \mathrm{df}$ \\
\hline .190 & 91 • و بالاتر & NFI \\
\hline .190 & 91 • و بالاتر & NNFI \\
\hline .191 & 91 • و بالاتر & AGFI \\
\hline .199 & 91 • و بالاتر & CFI \\
\hline .194 & 9 • • و بالاتر & GFI \\
\hline$\cdot 1 \cdot 4 \lambda$ & كوجكتر از 1 •|• & RMSEA \\
\hline
\end{tabular}

بحث

هدف مطالعه حاضر بررسى نقش واسطهاى سبكهاى مقابله با

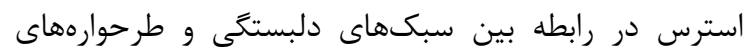

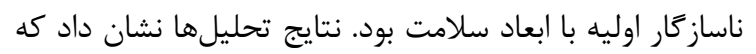
مدل ساختارى سبكهاى دلبستخى و طرحوارههاى ناساز گار

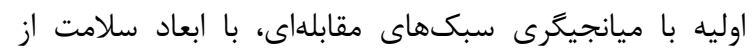

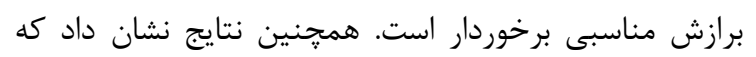

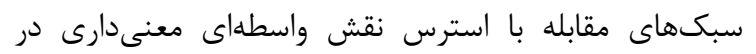
رابطه بين سبكهاى دلبستكى و طرحوارههاى ناساز مار اوليه

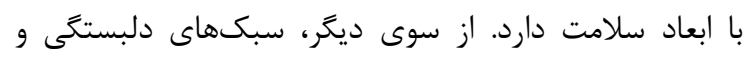

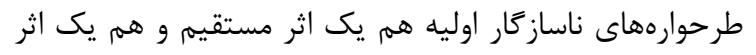

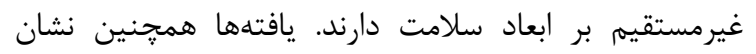

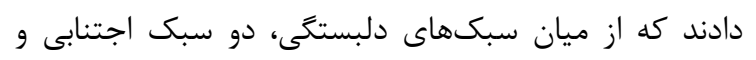
دوسو

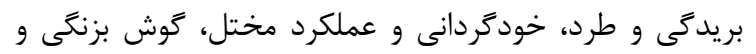

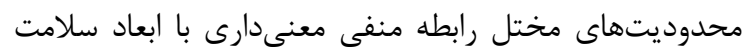

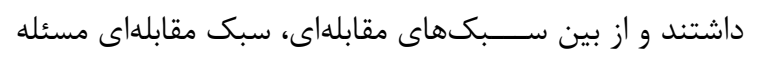

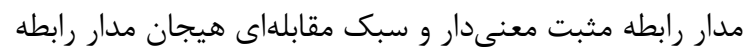

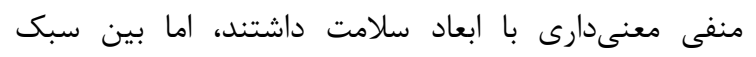

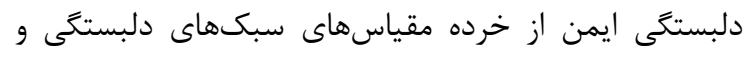

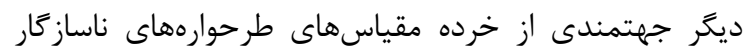

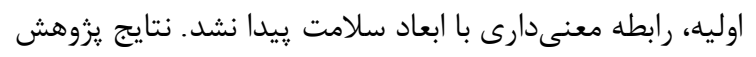

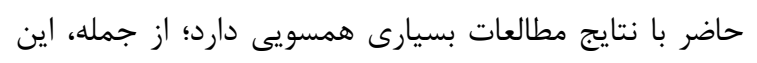

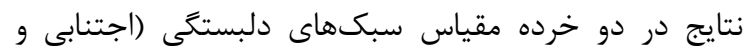

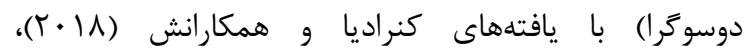

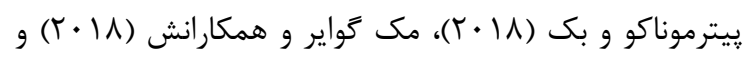

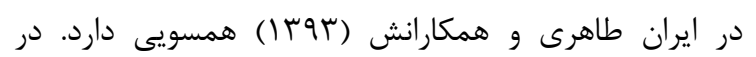

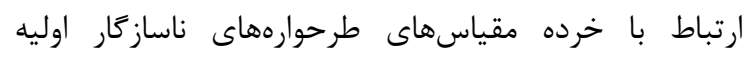

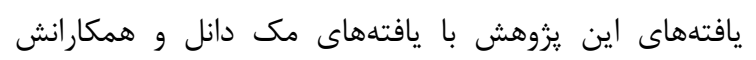
(Y.|N)
اين ضريب توانايى ويش بينى متغير وابسته توسط متغير

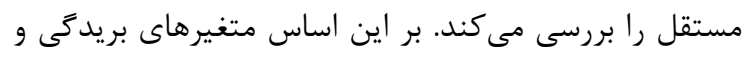

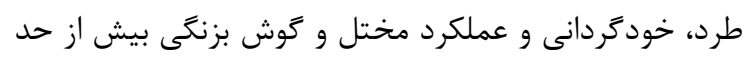

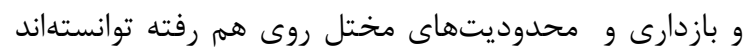

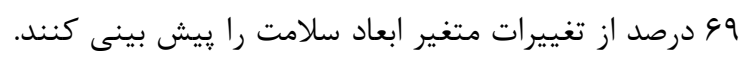

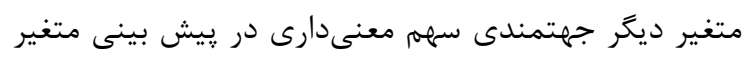

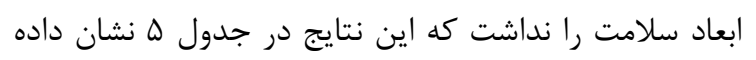

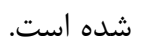
در حوزه سبكهاى مقابله با استرس و در ارتباط با اين

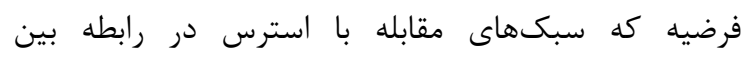

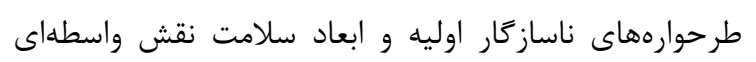

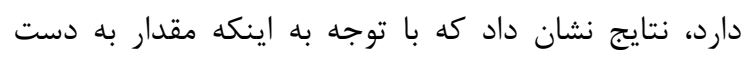

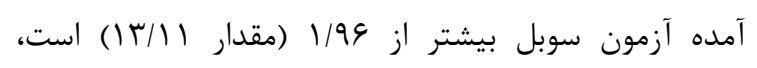

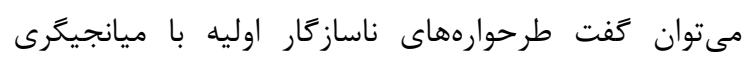
سبكهاى مقابلهاى بر ابعاد سلامت اثر غيرمستقيم دارد. باريا

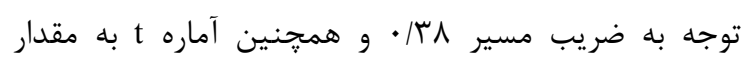

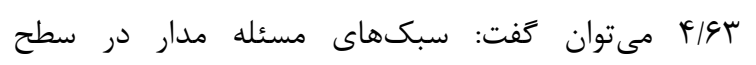

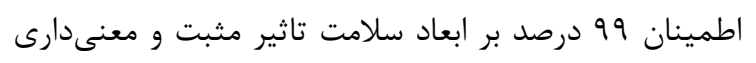

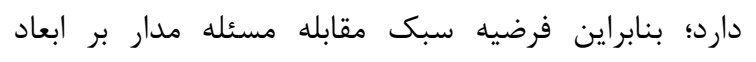

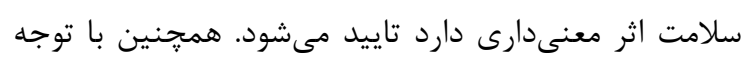

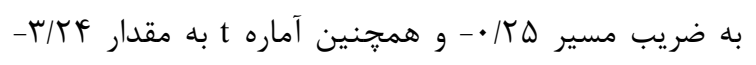
مىتوان كفت: سبكهاى هيجان مدار در سطح اطمينان 99

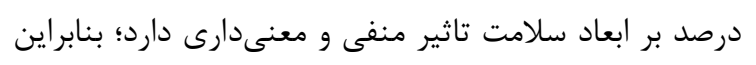

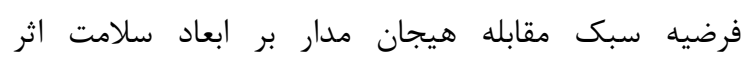

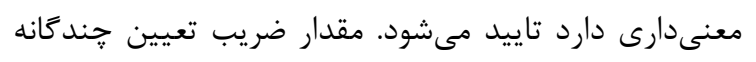

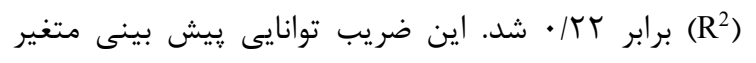

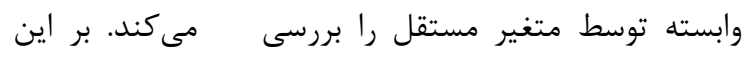

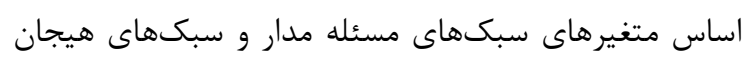

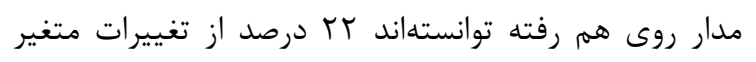

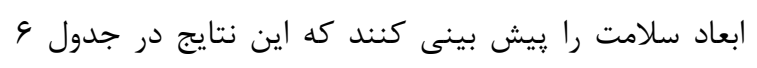
نشان داده شده است.

\section{مدل نهايى ندان داده شده ندان}

با توجه به نتايج به دست آمده در اين يروش مدل مدل نهايى به

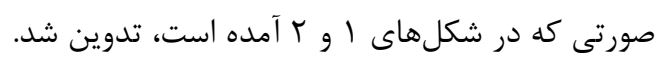

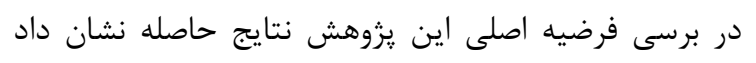

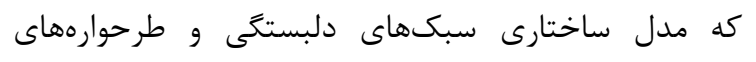

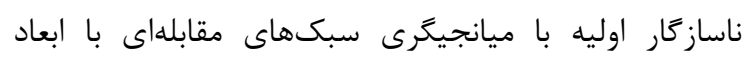

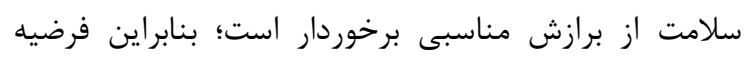

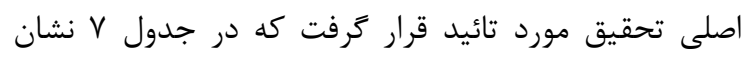

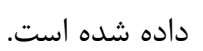


كنار آيند و از آنجايى كه فرد با طرحوارههايش احساس راحتى مى كند و نياز به هماهنكى شناختى دارد، براى بقا و تداوم طرحواره خود مى جنحد كه يكى از ساز و كارهايى كه به كار مى گيرد استفاده از سبك مقابلهاى ناسازگار است. به دنبال

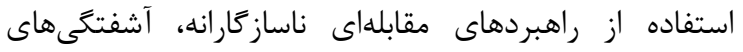
روانشناختى بيشترى را تجربه مى كنند و كيفيت سلامت آنها كاهش مىيابد (^^). بدين ترتيب، طرحوارههاى ناسازگًار اوليه از طريق واداشتن افراد به استفاده از راهبردهاى مقابلهاى

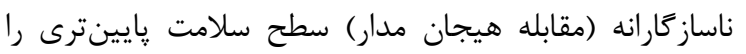
موجب مىشوند. به عنوان مثال، افرادى كه داراى

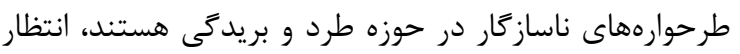

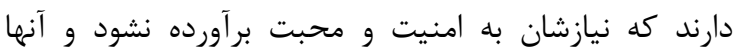
ممكن است در برابر احساس طرد و نايمنى از طريق يك راهبرد مقابلهاى نامؤثر محافظت كنند كه اين امر در يايين

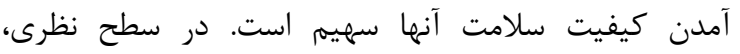
يافتههاى اين يزوهش ميىتواند موجب افزايش دانش روانشناختى ما در زمينه عوامل موثر بر شكل دهى و تداوم

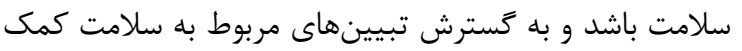

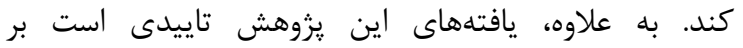
نظريههاى حاضر در زمينه رابطه بين سبكهاى دلبستگى،

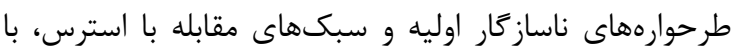
ابعاد سلامت و توجه به اين مطلب كه رابطه بين اين متغيرها ييجيده است و بررسى ساير متغيرها به منظور فهلم بهتر اين

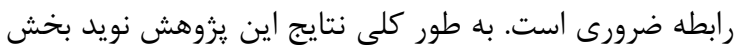
نغاهى نو به مقوله سلامت است كه براى تبيين بهتر نياز به ديدكاهى گسترده و همه جانبه دارد. در سطح عملى و به به بهرئ خصوص بالينى، اين يافتهها، متخصصان بهداشت روان از جمله

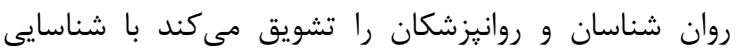
عوامل تاثيرگذار بتوانند رويكردهاى موثر، نوين و مقرون بـ رون صرفهاى را جهت ييشخيرى، درمان و ارتقاء سلامت جسمى و روانى مد نظر قرار دهند و با شناسايى به موقع عوامل ديل دئ مداخلهَر در بيمارى و سلامت، بتوانند هزينههاى تحميل شده به فرد، جامعه و سيستم بهداشت و درمان را كاهش درى دهند. بررسى شاخصهاى سلامت يك ضرورت بسيار مهرم در ارزيابى وضعيت سلامت جسمى، روانى و اجتماعى براى دست

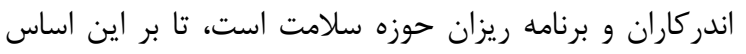

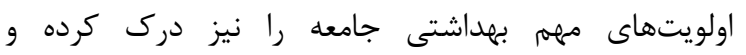
برنامههاى ارايه شده را به نحو مطلوبى اجرا كنند و با ارايه جهار جوب مفهومى شاخصهاى سلامت مىتوان يك مجموعه منسجم از شاخصهاى سلامت جسم و روان را ايجاد كرد.

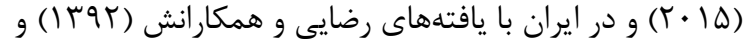

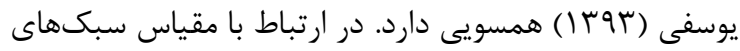

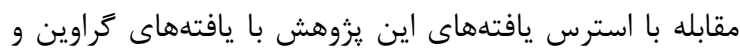

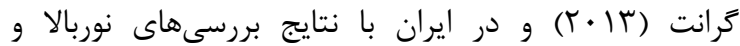

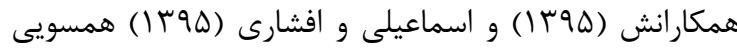
دارد. همجنين در خصوص ميانجيگرى سبكهاى مقابلهاى بين سبكهاى دلبستخى با و ابعاد سلامت يافتههاى اين

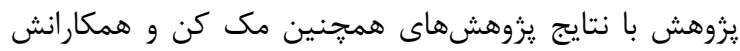

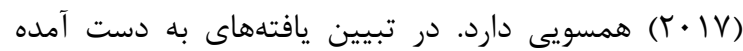
مىتوان جنين كفت كه تحقيقات قبلى حاكى از اين است كه تجارب دلبستتى، طرحوارهها و راهبردهاى مقابلهاى مىتوانند فاكتور موثرى در سلامت افراد باشد. با استناد به اين تحقيقات

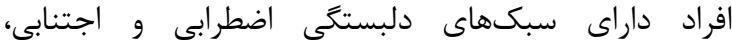
طرحوارههاى ناساز ₹ار و راهبردهاى مقابلهاى منفى در خطر برى ابتلا به انواع اختلالات جسمى و روانشناختى قرار دارند. افراد

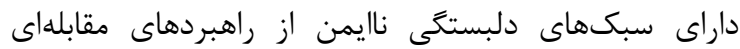

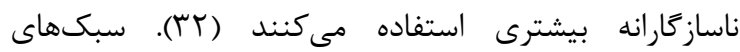

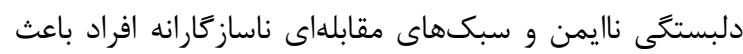
مىشود كه آنها در مقابله با موقعيتهاى استرسزا توانايى كمترى داشته باشند كه اين مسئله در كوتاه مدت با افزايش مولى اضطراب و در بلند مدت با كاهش حس خودكارآمدى فردى و افزايش آسيب يذيرى در برابر مشكلات جسمى و روانشناختى و كاهش سطح سلامت آنها همراه است (سب). همجنين آر

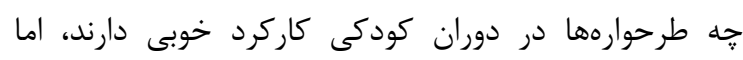
استفاده از آنها در سالهاى بعدى زندگى ناسازگًارانه است، زيرا

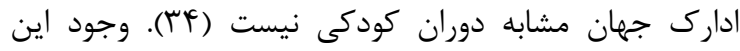

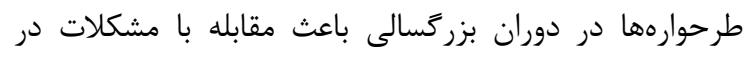

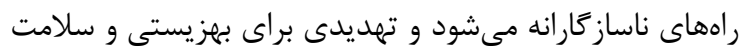
افراد به شمار مىرود. فعال شدن طرحوارههاى ناسازگًار اوليه منجر به ارزيابى منفى رويدادها و تعبير محركها به صورت

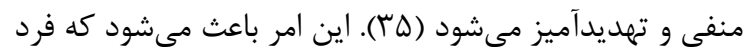
موقعيت فشارزا و توانايى خود براى مقابله با آن را به صورت

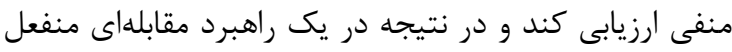

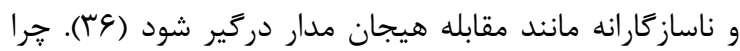

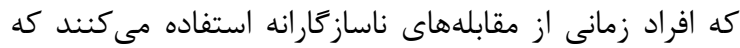
موقعيت استرسزا را غير قابل كنترل و دستكارى ادراك كنند (TV). از سوى ديخر فعال شدن طرحوارههاى ناسازگًار اوليه حجم عظيمى از هيجانهاى منفى و ناخوشايند را توليد

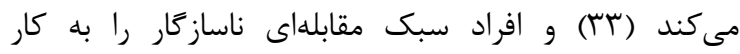
مىبندند تا با هيجانات آشفته ناشى از برانگيختتى طرحوارهها 


\section{REFERENCES}

1. Schwartz CE, Bode R, Repucci N, Becker J, Sprangers MA, Fayers PM. The clinical significance of adaptation to changing health: a meta-analysis of response shift. Qual Life Res 2006;15:1533-50.

2-Shojaei Tehrani H, Ebadi Fardazar F, Eds. Principles of health services. Tehran: Samatat Publications; 2007. [In Persian]

3- Waitley D, Ed. The psychology of winning. USA: Berkley Publishing; 2016. P.198630-2.

4-Bowlby J. The making and breaking of affectional bonds. London: Tavistock; 1979.

5-Conradia HJ, Kamphuis JH, de Jongeb P. Adult attachment predicts the seven-year course of recurrent depression in primary care. J Affect Disord 2018; 225: 160-66.

6- Pietromonaco PR, Beck LA. Adult attachment and physical health. Curr Opin Psychol 2019;25:115-120.

7-McGuire A, Gillath O, Jackson Y, Ingram R. Attachment security priming as a potential intervention for depressive symptoms. Journal of Social and Clinical Psychology 2018; 37: 44-68.

8-Taheri M, Hasani, J, Rezaei Jamalouee H. Prediction of health dimensions based on attachment styles and components of emotional intelligence. Journal of Clinical Care 2014;2:24-31. [In Persian]

9-Young JE, Klosko JS, Weishaar ME, Eds. Schema therapy: a practitioner's guide. New York: Guilford Press; 2003.

10-Yang J, Ed. Cognitive therapy of personality disorders, a scenario-focused approach; Translation: Sahebi A, Hamidpour H. Tehran: Arjomand Publication; 2005. [In Persian]

11-Yang J, Colosseau J, Vishar M, Eds. Schema therapy: a practical guide for clinical specialists. Translation: Hamidpour H, Endoz Z. First edition. Tehran: Arjmand Publishing; 2003. [In Persian]

12- Mc Donnell E, Hevey D, McCauley M, Ducray KN. Exploration of associations between early maladaptive schemas, impaired emotional regulation, coping strategies and resilience in opioid dependent poly-drug users. Subst Use Misuse 2018;53:2320-29.

13-Mącik D. Symptoms of mental health disorders and erly maladaptive schhemas- assessment of dependencies. Psychoterapia 2017;1:33-47.

14- Shorey RC, Elmquist J, Anderson S, Stuart GL. The relationship between early maladaptive schemas, depression, and generalized anxiety among adults seeking residential treatment for substance use disorders. J Psychoactive Drugs $2015 ; 47: 230-8$.

15-Rezaei M, Gholam Razaei S, Sehvandi MA, Ghazanfari F, Derrickand F. The power of early maladaptive schemas and personality dimensions in predicting depression. Thought and Behavior 2013;8:77-86. [In Persian]

16-Hobfoll SE, Schwarzer RC. Disentangling the stress labyrinth interpreting the meaning of the term stress and it is studied in health context.Anxiety. Stress Coping. 1998;11: 181-212.

17-Lazarus MLRS, Folkman S. The concept of coping in stress, Appraisal, and coping. 1984: New York, Springer.

18- Graven LJ, Grant JS. Coping and health-related quality of life in individuals with heart failure: an integrative review. Heart Lung. 2013;42:183-94.

19-Noorbala F, Bahrami E, Alipour A. The Effect of Avoidance and Extreme Counterfeit Coping Styles on Health; Journal of Health Psychology. 2016; 5:21-29. [In Persian]

20-Ismaili A, Afshari A. The study of the relationship between coping styles and early maladaptive schemas. $5^{\text {th }}$ International Conference of Psychology and Social Sciences, Tehran, Iran: 2016. [In Persian]

21- Annette M, Heron CJ, Thomson R, Nicholas D. Attachment, Coping, and Suicidal Behavior in Male Prisoners. Criminal Justice and Behavior. 2017; 44: 566-588.

22-Markus KA. Principles and Practice of Structural Equation Modeling by Rex B. Kline. Structural Equation Modeling. Multidisciplinary J. 2012:19:509-12.

23-Goldberg D. Manual of the general health questionnaire. 1978: Windsor: NFER Publishing Company.

24-Taqavi, SMR. Validity and validity of general health questionnaire on a group of students in Shiraz University, Journal of Psychology. 2002; 4: 381-398. [In Persian]

25-Basharat MA. Standardization of Adult Attachment Scale. Research Report, University of Tehran. 2005;11;42-47 [Persian] 
26-Basharat MA. Adult Attachment Scale: A Questionnaire, Method of Implementation and Grading. Developmental Psychology. 2013; 35: 32-317. [In Persian]

27-Besharat MA. Development and validation of Adult Attachment Inventory. Procedia - Social and Behavioral Sciences. 2011;30: 475-479. [In Persian]

28-Abbasids HR, Fatehizadeh M. Standardization of a short form of cognitive schema test on Isfahan University Students, Isfahan University [Master's thesis]. Isfahan: Isfahan University; 2003. [In Persian]

29- Soleimani M A, Pahlevan Sharif S, Yaghoobzadeh A, Sim Ong F. Relationship between hardiness and addiction potential in medical students. Iran J Psychiatry Behav Sci 2016; 10:e6225.

30-Saatchi M, Kamkar K, Ashgarian M, Eds. Psychological tests. Tehran: Virayesh Publishing; 2010. [In Persian]

31-Samii S. Psychometric properties of Lazarus Folman coping strategies questionnaire and its relationship with anxiety and self-efficacy of coping with problems [Master's Thesis]. Tehran: Islamic Azad University; 2014. [In Persian]

32-Linley PA, Joseph S. Positive change following trauma and adversity: a review. J Trauma Stress 2004;17:11 -21.

33-Shaver PR, Mikulincer M0. Adult attachment strategies and the regulation of emotion. In: Gross JJ, Ed. Handbook of emotion regulation. New York: Guilford Press; 2007. 446-65.

34- Yang J, Ed. Schema therapy. Translation: Hamidpour H, Endoz Z. First edition. Tehran: Arjmand Publishing; 2017. [In Persian]

35-Penley JA, Tomaka J. Associations among the Big five, emotional responses, and coping with acute stress. Personality and Individual Differences 2002;32: 1215-28.

36-BallS SJ, Shekhar A. A psychobiological approach to personality: examination within anxious outpatients. Psychiatric Res 2002;36: 97-103.

37-Karlsen B, Oftedal B, Bru E. The relationship between clinical indicators, coping styles, perceived support and diabetes-related distress among adults with type 2 diabetes. Journal of Advanced Nursing 2012; 68: 391-401.

38-Endler NS, Parker JDA. Multidimensional assessment of coping: task, emotion and avoidance strategies. Psychological Assessments 1994;6: 50-60. 